\title{
Pengembangan Learning Card untuk meningkatkan kerja sama tim dan pengetahuan mahasiswa: Literature Review
}

\author{
${ }^{1}$ Nastain Abubakar Pattimura*, ${ }^{2}$ Elsye Maria Rosa, \\ 1,2Program Studi Magister Keperawatan, Universitas Muhammadiyah Yogyakarta \\ Email : nastainabubakar@yahoo.com
}

\section{Kata Kunci : \\ Learning Card, \\ Kerja Sama Tim, \\ Pengetahuan \\ Keywords : \\ Learning Card, \\ Teamwork, \\ Knowledge}

Info Artikel :

Tanggal dikirim:

11 September 2020

Tanggal direvisi:

15 September 2020

Tanggal diterima :

18 September 2020

DOI Artikel:

10.33862/citradeli

ma.v4i2.118

Halaman: 85-93

\section{Abstrak}

Penggunaan Learning Card bergambar bertujuan untuk mempermudah mahasiswa memberikan asosiasi terhadap konsep dan materi sehingga gambar yang didapatkan mahasiswa dalam memunculkan ide-ide yang kreatif. Kartu tendang bergambar diharapkan mampu meningkatkan mahasiswa kemampuan spasial dan visual mahasiswa. Tujuan dari Literature Review ini untuk melakukan review terhadap artikelartikel yang meneliti tentang Pengembangan Learning Card terhadap Peningkatan Kerja Sama Tim dan Pengetahuan Mahasiswa. Data yang digunakan berasal dari jurnal yang berisikan tentang konsep yang diteliti. Proses pengumpulan data dilakukan dengan penyaringan dari 17.071 sumber literatur menjadi 7 literatur berdasarkan kriteria yang ditentukan oleh Penulis dari setiap jurnal yang diambil. Adapun kriteria yang dimaksud meliputi tahun sumber literatur yang diambil mulai tahun 2014 sampai dengan 2019, kesesuaian keyword penulisan, keterkaitan hasil penulisan dan pembahasan. Strategi dalam pengumpulan jurnal berbagai literatur dengan menggunakan situs jurnal yang sudah terakreditasi seperti Google Scholar, Science Direct dan juga BMC Medical Education. Cara penulisan yang efektif untuk setting jurnal dengan memasukkan kata kunci sesuai judul Penulisan seperti "Learning Card AND Teamwork AND Knowledge. Pada kartu Learning merupakan kartu yang berisikan kata kunci dalam pembelajaran yang digunakan mahasiswa dalam menyusun solusi, konsep dan pemecahan masalah baik secara runut dan sistematis.

\section{Learning Card development to enhance teamwork and student knowledge: Literature Review}

\section{Abstract}

The use of pictorial Learning Cards aims to make it easier for students to provide associations with concepts and materials so that the images that students get can generate creative ideas. The pictorial kick card is expected to improve students' spatial and visual abilities. The purpose of this Literature Review is to review articles that examine Learning Card Development towards Improving Student Teamwork and Knowledge. The data used comes from journals that contain the concepts under study. The data collection process was carried out by filtering from 17,071 literary sources to 7 literatures based on the criteria determined by the author of each journal taken. The criteria referred to include the year the literature sources were taken from 2014 to 2019 , the suitability of writing keywords, the relationship between the results of writing and discussion. Strategies in collecting journals for various literatures using accredited journal sites such as Google Scholar, Science Direct and BMC Medical Education. An effective way of writing for journal settings is by entering keywords according to the writing title such as "Learning Card AND Teamwork AND Knowledge. On the Learning card is a card that contains keywords in learning that are used by students in preparing solutions, concepts and problem solving both sequentially and systematically.

http://jurnalilmiah.stikescitradelima.ac.id/index.php/JI

Vol.4, No.2, Januari 2021 


\section{PENDAHULUAN}

Pendidikan merupakan usaha untuk mengembangkan dan membina potensi sumber daya manusia melalui berbagai kegiatan belajar mengajar yang diselenggarakan pada semua jenjang pendidikan dari tingkat dasar, menengah, dan perguruan tinggi. Pendidikan di sekolah mempunyai tujuan untuk mengubah siswa agar dapat memiliki pengetahuan, ketrampilan, dan sikap belajar sebagai bentuk perubahan perilaku belajar, sehingga tujuan pendidikan tercapai. Dengan adanya tujuan tersebut, maka mutu pendidikan akan dapat ditingkatkan (Wahyudin D, 2011).

Masalah utama dalam pembelajaran pada pendidikan formal (sekolah) dewasa ini adalah masih rendahnya daya serap peserta didik sebab orientasi pembelajaran hanya terkait dengan aspek kognitif, hal ini tentu saja tidak mengejutkan sebab jika kita amati selama pembelajaran kebermaknaan pembelajaran belum nampak sehingga siswa hanya dipaksa menghafal konsep tetapi belum mampu mengaitkan pembelajaran dengan dunia nyata sehingga tak jarang hal tersebut turut mempengaruhi prestasi peserta didik dan tidak menyentuh ranah dimensi peserta didik itu sendiri, yaitu bagaimana sebenarnya belajar itu (belajar untuk belajar) sehubungan dengan hal tersebut guru dapat menerapkan strategi yang tepat untuk dapat meningkatkan pemahaman siswa dan Salah satu strategi yang dapat disarankan untuk masalah ini adalah pembelajaran kooperatif yang menggunakan kartu pintar hal ini diharapkan dapat membantu siswa dalam mengorganisasi sesuatu mulai dari informasi, fakta, konsep ke dalam suatu konteks pemahaman, sehingga terbentuk pemahaman yang baik (Wahyudin D, 2011).

Hal yang diinginkan dengan adanya penggunaan model pembelajaran ini dapat terjadi peningkatan pemahaman siswa pada materi pelajaran. Kemudian aktivitas siswa mengalami peningkatan jauh lebih besar dan respon yang diperlihatkan siswa positif dan menganggap pelajaran menyenangkan sehingga proses belajar mengajar adanya interaksi antara guru dengan siswa. Interaksi antara guru dan siswa dapat diciptakan melalui penggunaan pendekatan-pendekatan pembelajaran, metode pembelajaran dan strategi pembelajaran yang sesuai dengan tuntutan kurikulum, materi, media, dan evaluasi serta kondisi dan lingkungan sekolah (Nurdiansyah and Fariyatul Fahyuni, 2016).

\section{METODE}

\section{Tujuan}

Tujuan dari Literature Review ini untuk melakukan review terhadap artikel-artikel yang meneliti tentang Pengembangan Learning Card terhadap Peningkatan Kerja Sama Tim dan Pengetahuan Mahasiswa.

\section{Strategi Pencarian}

Studi literatur adalah cara yang dipakai untuk menghimpun data atau sumber-sumber yang berhubungan dengan topik yang diangkat dalam suatu penulisan. Studi literatur bisa didapat dari berbagai sumber baik jurnal, buku, dokumentasi, internet dan pustaka. Metode studi literatur adalah serangkaian kegiatan yang berkenaan dengan metode pengumpulan data pustaka, membaca dan mencatat, serta mengelolah bahan penulisan(Stigmar, 2016). Jenis penulisan yang digunakan adalah studi literatur review yang berfokus pada hasil penulisan yang berkaitan dengan topik atau variabel penulisan Penulis melakukan studi literatur ini dilakukan oleh penulis setelah mereka menentukan topik penulisan dan ditetapkannya rumusan masalah, sebelum terjun ke lapangan untuk mengumpulkan data yang diperlukan (Rodríguez-Carrio et al., 2018)

Data yang digunakan berasal dari jurnal yang berisikan tentang konsep yang diteliti. Proses pengumpulan data dilakukan dengan penyaringan dari 17.071 sumber literatur menjadi 8 literatur berdasarkan kriteria yang ditentukan oleh Penulis dari setiap jurnal yang diambil. (Stigmar, 2016) Adapun kriteria yang dimaksud meliputi tahun sumber literatur yang diambil mulai tahun 2014 sampai dengan 2019, kesesuaian keyword penulisan, keterkaitan hasil penulisan dan pembahasan. Strategi dalam pengumpulan jurnal berbagai literatur dengan menggunakan situs jurnal yang sudah terakreditasi seperti Google Scholar, Science Direct dan juga BMC Medical Education. Cara penulisan yang efektif untuk setting jurnal dengan memasukkan kata kunci sesuai judul Penulisan seperti "Learning Card AND Teamwork AND Knowledge (Stigmar, 2016)

Penelitian ini menggunakan metode Literature review yang relevan ditinjau mengikuti

http://jurnalilmiah.stikescitradelima.ac.id/index.php/JI Vol.4, No.2, Januari 2021 
pencarian dari 3 database yaitu Google Scholar, Science Direct dan BMC Medical Education.

\section{Kriteria Inklusi dan Eklusi}

Memulai dengan materi hasil penulisan yang secara sekuensi diperhatikan dari yang paling relevan, dan cukup relevan. Cara lain, misalnya dengan melihat tahun penulisan (tahun 2014-2019). Membaca abstrak setiap jurnal terlebih dahulu untuk memberikan penilaian apakah permasalahan yang dibahas sesuai dengan yang hendak dipecahkan dalam suatu jurnal. Mencatat point-point penting dan relevansinya dengan permasalahan penelitian, Untuk menjaga tidak terjebak dalam unsur plagiat, penulis hendaknya juga mencatat sumber-sumber informasi dan mencantumkan daftar pustaka. Jika memang informasi berasal dari ide atau hasil penulisan orang lain. Membuat catatan, kutipan, atau informasi yang disusun secara sistematis sehingga penulisan dengan mudah dapat mencari kembali jika sewaktu-waktu diperlukan (Presti, 2016)

Setiap jurnal yang telah dipilih berdasarkan kriteria, dibuat sebuah kesimpulan yang menggambarkan penjelasan terkait tentang pengembangan Learning Card terhadap Peningkatan Kerja Sama Tim dan Pengetahuan Mahasiswa. Sebelum penulis membuat kesimpulan dari beberapa hasil literatur, penulis akan mengidentifikasi dalam bentuk ringkasan secara singkat berupa tabel yang berisi nama penulis, tahun penulisan, rancangan studi, intervensi, sampel, instrumen (alat ukur), hasil dan konflik teori. Setelah hasil penulisan dari beberapa literatur sudah dikumpulkan, penulis akan menganalisa pengembangan Learning Card apa saja yang dilakukan oleh mahasiswa keperawatan terhadap peningkatan kerja sama tim dan pengetahuan dalam bentuk pembahasan. Kriteria inklusi pada literature ini yaitu artikel bahasa inggris dengan tanggal publikasi 3 tahun terakhir mulai dari tahun 2014 sampai dengan tahun 2019, artikel dalam bentuk Free full teks. Kriteria ekslusi yaitu artikel publikasi tidak dalam bentuk publikasi tidak asli seperti surat ke editor, abstrak saja dan buku (Vickrey et al., 2015)
Tabel. 1 Kriteria Inklusi dan Eksklusi

\begin{tabular}{|c|c|}
\hline Inklusi & Eklusi \\
\hline 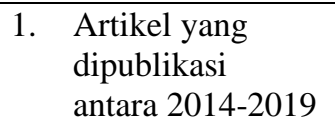 & $\begin{array}{ll}\text { 1. } & \text { Tidak sesuai } \\
\text { dengan literatur } \\
\text { yang dibutuhkan }\end{array}$ \\
\hline $\begin{array}{l}\text { 2. Artikel yang } \\
\text { dipublikasi } \\
\text { dalam bahasa } \\
\text { inggris }\end{array}$ & $\begin{array}{l}\text { 2. Artikel } \\
\text { Pembelajaran pada } \\
\text { mahasiswa } \\
\text { keperawatan bukan }\end{array}$ \\
\hline $\begin{array}{l}\text { 3. Edukasi Family } \\
\text { Therapy }\end{array}$ & $\begin{array}{l}\text { untuk mahasiswa } \\
\text { selain keperawatan }\end{array}$ \\
\hline $\begin{array}{l}\text { mencegah } \\
\text { Bullying pada } \\
\text { anak sebagai }\end{array}$ & $\begin{array}{l}\text { 3. Artikel tidak asli, } \\
\text { seperti surat ke } \\
\text { editor }\end{array}$ \\
\hline $\begin{array}{l}\text { topik utama } \\
\text { 4. Memiliki abstrak } \\
\text { dan fulltext }\end{array}$ & $\begin{array}{l}\text { 4. Artikel hanya } \\
\text { abstrak }\end{array}$ \\
\hline
\end{tabular}

\section{Hasil Pencarian}

Fokus utama dari literatur review ini adalah pada Penerapan Learning Card terhadap Peningkatan Kerja Sama Tim dan Pengetahuan Mahasiswa. Hasil pencarian melalui review Sebanyak 17.071 jurnal diidentifikasi dan dilakukan kriteria kelayakan. Kemudian setelah itu disaring didapatkan 1.654 jurnal, setelah itu excluded studies lagi berdasarkan kriteria inklusi sehingga jumlah total artikel yang memenuhi syarat untuk review adalah 8 jurnal sebagaimana digambarkan dalam Gambar 1.

Di antara hasil 7 jurnal yang di review, terdapat jurnal yang memiliki desain berbeada-beda yang pertama memiliki desain Quasi Eksperimental (Kalisch et al., 2015), yang kedua memiliki desain penilitian Studi Survei, Kualitatif (Holland and Ulrich, 2016), ketiga memiliki desain penilitian Desain prospektif, satu kelompok, pra-dan pasca-tes (Park et al., 2015), keempat Studi Survei (Eliasa, 2014), kelima memiliki desai Kualitatif Quasi-Eksperimental (Tofil et al., 2014), keenam desain Kualitatif (Jones and Alinier, 2015), dan yang ketujuh memiliki desain ELearning sistem authoring CASUS (Jäger et al., 2014)

http://jurnalilmiah.stikescitradelima.ac.id/index.php/JI Vol.4, No.2, Januari 2021 


\section{Gambar 1. Proses Pencarian Artikel}

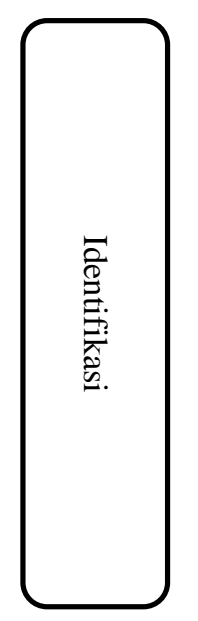

Hasil Pencarian dari 3 database : $(\mathbf{n}=\mathbf{1 7 . 0 7 1})$; BMC: $\mathrm{n}=135$; Science Direct: $\mathrm{n}=\mathbf{4 3 6}$
Sumber Lain :

Google Scholar: $\mathrm{n}=\mathbf{1 7 . 5 0 0}$,

Setelah artikel yang sama dikeluarkan $(\mathbf{n}=\mathbf{1 . 6 5 4})$

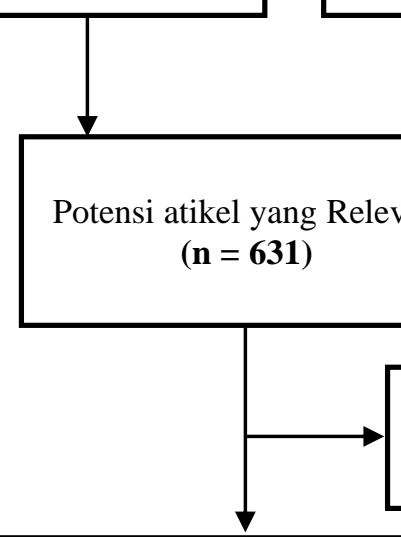

Artikel dikeluarkan Setelah dievaluasi judulnya

$(\mathbf{n}=\mathbf{5 3 8})$

Hasil pembacaan judul:

$(\mathbf{n}=93)$

BMC (n=23), Science Direct: $(\mathbf{n}=\mathbf{1 9})$,

Google Scholar: $(\mathbf{n = 5 1})$

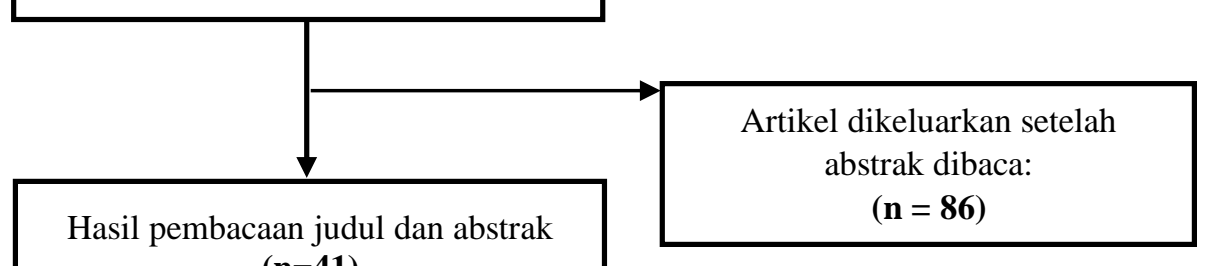

BMC $(\mathbf{n}=\mathbf{1 0})$, Science Direct $(\mathbf{n = 1 4})$,

Google scholar (n=17)
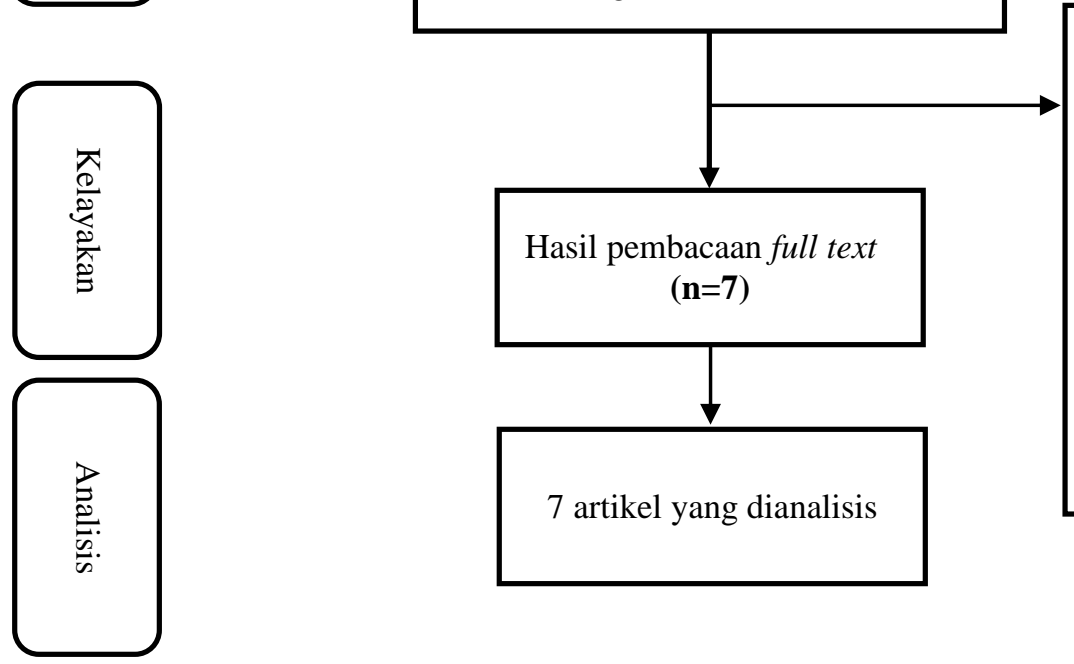

Full text yang di masukkan:

1. Artikel yang dipublikasi antara 2014-2019

2. Artikel yang dipublikasi dalam bahasa inggris

3. Artikel yang relevan dengan literatur review dan sesuai dengan kriteria inklusi dan eksklusi

4. Memiliki abstrak dan fulltext

http://jurnalilmiah.stikescitradelima.ac.id/index.php/JI Vol.4, No.2, Januari 2021 
Tabel 2. Kesimpulan keseluruhan artikel yang terinklude

\begin{tabular}{|c|c|c|c|c|c|c|}
\hline No & $\begin{array}{l}\text { Peneliti } \\
\text { (Tahun) }\end{array}$ & Judul & Study design & $\begin{array}{l}\text { Partisipan } \\
\text { /Sample }\end{array}$ & Instrumen & Temuan \\
\hline 1. & $\begin{array}{c}\text { Beatrice J. } \\
\text { Kalisch } \\
(2015)\end{array}$ & $\begin{array}{l}\text { Intervensi untuk } \\
\text { Tingkatkan } \\
\text { Keperawatan } \\
\text { Kerja Tim } \\
\text { Menggunakan } \\
\text { Virtual } \\
\text { Simulasi }\end{array}$ & $\begin{array}{c}\text { Quasi- } \\
\text { Eksperimental }\end{array}$ & $43 \mathrm{Staf}$ & $\begin{array}{c}\text { Simulasi } \\
\text { Virtual }\end{array}$ & $\begin{array}{l}\text { Rata-rata keseluruhan skor kerja tim } \\
\text { meningkat dari pra- }(\mathrm{M}=3,25, \mathrm{SD}=0,58) \\
\text { ke pasca-intervensi }(\mathrm{M}=3,49, \mathrm{SD}=0,67, \mathrm{p} \\
<0,012) \text {. Intervensi juga besar }(0,60 \leq \mathrm{d} \leq \\
0,97) \text { dan efek signifikan pada ukuran tiga } \\
\text { kerja tim subskala (mis., kepercayaan, } \\
\text { orientasi tim, dan cadangan). Meskipun } \\
\text { investigasi yang lebih besar } \\
\text { membandingkan pendekatan ini dengan } \\
\text { yang lebih tradisional pelatihan diperlukan, } \\
\text { penelitian ini menunjukkan kelayakan } \\
\text { implementasi pelatihan simulasi virtual } \\
\text { dengan anggota staf perawat. }\end{array}$ \\
\hline 2. & $\begin{array}{l}\text { Cindra } \\
\text { Holland } \\
\text { DNP } \\
(2016)\end{array}$ & $\begin{array}{l}\text { Kartu pemikiran } \\
\text { kritis: Pengajaran } \\
\text { yang inovatif } \\
\text { strategi untuk } \\
\text { menjembatani } \\
\text { pengetahuan kelas } \\
\text { dengan klinis } \\
\text { pengambilan } \\
\text { keputusan }\end{array}$ & $\begin{array}{l}\text { Studi Survei, } \\
\text { Kualitatif }\end{array}$ & 66 Siswa & Kuesioner & $\begin{array}{l}\text { Siswa dan fakultas dalam kursus kebidanan } \\
\text { disurvei mengenai penggunaan kartu } \\
\text { berpikir kritis sebagai strategi pengajaran } \\
\text { aktif dalam pengaturan klinis. Kartu } \\
\text { berpikir kritis adalah fondasi bagi seorang } \\
\text { yang aktif strategi pembelajaran yang } \\
\text { menggabungkan tanya jawab, pemecahan } \\
\text { masalah, pelatihan, dan berpikir-keras } \\
\text { pendekatan sambil menggunakan } \\
\text { pemikiran tingkat tinggi untuk } \\
\text { meningkatkan pengambilan keputusan } \\
\text { klinis }\end{array}$ \\
\hline 3. & $\begin{array}{l}\text { Hyung- } \\
\text { Ran Park } \\
(2015)\end{array}$ & $\begin{array}{l}\text { Efek } \\
\text { pembelajaran } \\
\text { berbasis tim pada } \\
\text { persepsi kerja tim } \\
\text { dan kinerja } \\
\text { akademik dalam } \\
\text { mata pelajaran } \\
\text { penilaian } \\
\text { kesehatan }\end{array}$ & $\begin{array}{l}\text { Desain } \\
\text { prospektif, } \\
\text { satu } \\
\text { kelompok, } \\
\text { pra-dan pasca- } \\
\text { tes }\end{array}$ & 74 Siswa & Kuesioner & $\begin{array}{l}\text { Hasil penelitian menunjukkan } \\
\text { pembelajaran berbasis tim dapat menjadi } \\
\text { strategi pembelajaran dan pengajaran yang } \\
\text { efektif untuk meningkatkan tim- pekerjaan } \\
\text { mahasiswa keperawatan, yang perlu } \\
\text { berkolaborasi dan berkomunikasi secara } \\
\text { efektif dengan kesehatan penyedia layanan } \\
\text { untuk meningkatkan kesehatan pasien. }\end{array}$ \\
\hline 4. & $\begin{array}{c}\text { Eva Imania } \\
\text { Eliasa } \\
(2014)\end{array}$ & $\begin{array}{l}\text { Meningkatkan } \\
\text { Nilai Kerja } \\
\text { dan Sama } \\
\text { Jawab Tanggung } \\
\text { Melalui Siswa } \\
\text { Permainan: } \\
\text { Mengintegrasikan }\end{array}$ & Studi Survei & & Permainan & $\begin{array}{l}\text { Temuannya menunjukkan bahwa ada } \\
\text { peningkatan } 4,05 \text { poin untuk kerjasama dan } \\
6.14 \text { poin untuk tanggung jawab yang } \\
\text { dilakukan setelah memberikan siswa } \\
\text { beberapa kegiatan melalui permainan. Pada } \\
\text { awalnya, siswa masih malu untuk meminta } \\
\text { teman-teman mereka untuk bekerja sama }\end{array}$ \\
\hline
\end{tabular}

http://jurnalilmiah.stikescitradelima.ac.id/index.php/JI 


\begin{tabular}{|c|c|c|c|c|c|c|}
\hline & & $\begin{array}{l}\text { Karakter } \\
\text { Pendidikan dalam } \\
\text { Kuliah }\end{array}$ & & & & $\begin{array}{l}\text { dalam permainan, tetapi akhirnya mereka } \\
\text { menyadari betapa pentingnya kerja sama } \\
\text { jika mereka ingin mendapatkan hasil } \\
\text { maksimal }\end{array}$ \\
\hline 5. & $\begin{array}{l}\text { Nancy M. } \\
\text { Tofil, MD, } \\
\text { MEd1, } \\
\text { (2014) }\end{array}$ & $\begin{array}{l}\text { Pelatihan Simulasi } \\
\text { Interprofesional } \\
\text { Meningkatkan } \\
\text { Pengetahuan dan } \\
\text { Kerja Tim dalam } \\
\text { Keperawatan dan } \\
\text { Mahasiswa } \\
\text { Kedokteran } \\
\text { Selama } \\
\text { Panitera } \\
\text { Kedokteran } \\
\text { Internal }\end{array}$ & $\begin{array}{c}\text { Kualitatif } \\
\text { Quasi- } \\
\text { Eksperimental }\end{array}$ & 108 Siswa & Kuesioner & $\begin{array}{l}\text { Simulasi interprofesional yang imersif } \\
\text { dapat dilakukan } \\
\text { diimplementasikan dengan medis tahun } \\
\text { ketiga siswa dan mahasiswa keperawatan } \\
\text { senior. Para peserta, terlepas dari profesi, } \\
\text { memiliki peningkatan yang signifikan } \\
\text { dalam pengetahuan klinis. Peserta ini juga } \\
\text { meningkatkan sikap mereka terhadap } \\
\text { interprofessional kerja tim dan kejelasan } \\
\text { peran }\end{array}$ \\
\hline 6. & $\begin{array}{l}\text { Indra } \\
\text { Jones, } \\
(2015)\end{array}$ & \begin{tabular}{lr}
\multicolumn{2}{l}{ Mendukung } \\
Pengalaman \\
Belajar Siswa \\
melalui $\quad$ Kartu \\
Ukuran Isyarat \\
Saku Dirancang di \\
sekitar & Kerangka \\
Simulasi & Reflektif
\end{tabular} & Kualitatif & 72 Siswa & Kuesioner & $\begin{array}{l}\text { Sebagian besar siswa menganggap RSF } \\
\text { sebagai alat yang berguna untuk } \\
\text { pembelajaran postimulation. (89\%) siswa } \\
\text { juga mengindikasikan bahwa hal itu akan } \\
\text { lebih mendorong mereka untuk } \\
\text { merefleksikan pembelajaran mereka di } \\
\text { praktik klinis, khususnya untuk } \\
\text { keterampilan praktis/teknis seperti } \\
\text { penilaian dan diagnosis pasien. } \\
\text { Khususnya, penggunaan RSF untuk } \\
\text { identifikasi kebutuhan pembelajaran } \\
\text { teoretis dinilai jauh lebih rendah }(22,2 \%) \text {. }\end{array}$ \\
\hline 7. & & $\begin{array}{l}\text { Pasien virtual: } \\
\text { pengaruh desain } \\
\text { kasus dan kerja } \\
\text { tim pada persepsi } \\
\text { dan pengetahuan } \\
\text { siswa - studi } \\
\text { percontohan }\end{array}$ & $\begin{array}{l}\text { E-Learning } \\
\text { sistem } \\
\text { authoring } \\
\text { CASUS }\end{array}$ & 46 Siswa & Kuesioner & $\begin{array}{l}\text { Hasil: Siswa dengan lebih banyak } \\
\text { pengalaman klinis dan siswa yang telah } \\
\text { bekerja dalam tim menunjukkan kinerja } \\
\text { yang lebih baik pada pertanyaan MC. Siswa } \\
\text { dengan pengalaman klinis yang lebih } \\
\text { sedikit lebih sering menggunakan informasi } \\
\text { yang telah diposisikan kurang menonjol } \\
\text { bahan kasing }\end{array}$ \\
\hline
\end{tabular}

\section{HASIL DAN PEMBAHASAN}

Penggunaan kartu Learning bergambar bertujuan untuk mempermudah mahasiswa memberikan asosiasi terhadap konsep dan materi sehingga gambar yang didapatkan mahasiswa dalam memunculkan ide-ide yang kreatif. Kartu tendang bergambar diharapkan mampu meningkatkan mahasiswa kemampuan spasial dan visual siswa. Masalah yang disampaikan oleh dosen pada saat pembelajaran berlangsung dapat dibantu pemecahannya melalui gambar tersebut.

Pada kartu Learning merupakan kartu yang berisikan kata kunci dalam pembelajaran yang digunakan mahasiswa dalam menyusun solusi, konsep dan pemecahan masalah baik secara runut dan sistematis. Penggunaan kata kunci ini tentu saja harus sangat berkaitan dengan konsep yang dilontarkan oleh Dosen. Pada kartu Learning berkata terjadi penyusun ide kedalam sebuah solusi yang mampu dilaksanakan.

http://jurnalilmiah.stikescitradelima.ac.id/index.php/JI Vol.4, No.2, Januari 2021 
Kartu Learning berkata secara tidak langsung membantu mahasiswa dalam menemukan konsep yang dirancang sejak awal oleh dosen selain itu keterampilan berpikir kreatif siswa juga terasah, selain itu kemampuan verbal dan menulis siswa menjadi salah satu prioritas (Nurdyansyah and Fahyuni, 2016).

\section{Definisi pembelajaran Membuat Pasangan Menggunakan Learning Card}

Metode Make a Match (membuat pasangan) menggunakan Learning Card (Kartu Belajar) merupakan salah satu jenis dari metode dalam pembelajaran kooperatif. Salah satu keuntungan teknik ini adalah siswa mencari pasangan kartu learning sambil belajar mengenai suatu konsep atau topik, dalam suasana yang menyenangkan.

\section{Model Pembelajaran kooperatif modifikasi Mengunakan Learning Card}

Modifikasi Model pembelajaran ini menggunakan Learning Card yakni kartu yang berisikan kata-kata atau gambar yang digunakan untuk memicu ide baru dalam proses pembelajaran, Learning Card ini dirancang untuk memunculkan ide dalam spembelajaran untuk dapat menulis cerita dan menemukan konsep serta solusi terhadap permasalahan melalui pendekatan yang sederhana, Learning Card memiliki tujuan untuk menstimulasi pemikiran secara lateral sehingga diharapkan memicu berpikir kreatif siswa untuk menghasilkan ide-ide yang baru namun terarah.

Penggunaan Learning Card bergambar bertujuan untuk mempermudah siswa memberikan asosiasi terhadap konsep dan materi sehingga gambar yang didapatkan siswa dalam memunculkan ide-ide yang kreatif. Kartu tendang bergambar diharapkan mampu meningkatkan mahasiswa kemampuan spasial dan visual mahasiswa. Masalah yang disampaikan oleh dosen pada saat pembelajaran berlangsung dapat dibantu pemecahannya melalui gambar tersebut. Learning Card bergambar dapat digunakan pada mahasiswa di perguruan tinggi sebab dengan adanya gambar tersebut mampu menarik perhatian sekaligus membantu mahasiswa dalam pengasosiasian konsepnya.

\section{Langkah-Langkah pembelajaran Membuat Pasangan Menggunakan Learning Card}

Penerapan metode ini dimulai dengan teknik, yaitu mahasiswa disuruh mencari pasangan kartu Learning yang merupakan jawaban/soal sebelum batas waktunya, siswa yang dapat mencocokkan kartunya diberi poin. Langkah-langkah pembelajaran adalah sebagai berikut.

1. Dosen menyiapkan beberapa kartu yang berisikan beberapa konsep/topik yang cocok untuk sesi review.

2. Setiap mahasiswa memilih pasangannya 2 sampai 4 orang untuk bermain kartu yang telah disediakan

3. Mahasiswa membagikan kartu yang telah disediakan kepada pasangannya samapai kartunya habis.

4. Mahasiswa mencari pasangan yang mempunyai kartu yang cocok dengan kartunya.

5. Mahasiswa dapat mencocokkan kartunya sebelum batas waktu diberi.

6. Setelah itu Mahasiswa menjatuhkan kartunya satu persatu dan mencocokkan dengan fungsinya, samapai seterusnya

7. Evaluasi.

\section{Bentuk Desain Learning Card}

Rancangan ini berbentuk benda atau alat yang berbentuk Kartu yang dapat dijadikan sebagai media pembelajaran untuk meningkatkan kerja sama tim dan pengetahuan belajar mahasiswa.

\section{Kerja Sama Tim}

Aspek penting lainnya adalah kerja tim, yang dimiliki ditunjukkan untuk mengaktifkan peserta didik dan untuk meningkatkan pengetahuan dan, karenanya, mungkin juga relevan untuk motivasi dan retensi pengetahuan peserta didik ketika bekerja. Dalam sebuah studi oleh (Edelbring, 2012 dalam Jäger et al., 2014), siswa melaporkan manfaat yang dirasakan untuk klinis mereka keterampilan penalaran bekerja dengan pasangan dan mendiskusikan aplikasi manajemen pasien (Jäger et al., 2014)

\section{Pengetahuan}

Pengetahuan adalah merupakan hasil "tahu" dan ini terjadi setelah orang mengadakan penginderaan terhadap suatu objek tertentu. Proses pengindraan tersebut tentunya melalui panca indra yang ada pada manusia. Panca indra pada manusia tediri dari http://jurnalilmiah.stikescitradelima.ac.id/index.php/JI Vol.4, No.2, Januari 2021 
penglihatan, penciuman, pendengaran, serta merasakan sesuatu melalui perabaan. Proses pengindraan sehingga menghasilkan sebuah pengetahuan sangat dipengaruhi oleh intensitas perhatian persepsi terhadap obyek. Pengetahuan manusia sebagian besar diperoleh melalui mata dan telinga. (Nurhamsyah et al., 2015)

Dari definisi tersebut diperoleh ciri-ciri ilmu pengetahuan yaitu; sistematis, objektif, rasional, general, reliabel dan komunitas. Sistematis mengandung makna ilmu pengetahuan disusun secara berurutan atau teratur yang memiliki fakta-fakta penting yang saling berkaitan. Objektif berarti menjelaskan apa adanya sesuai dengan fenomena yang terjadi. Sementara rasional bermakna bersumber pada pemikiran rasio yang mematuhi kaidah-kaidah logika.

Adapun obyek dalam ilmu pengetahun terbagi menjadi dua; obyek material dan formal. Obyek material adalah obyek yang dihadirkan dalam pemikiran atau penelitian; baik yang bersifat materi (seperti benda-benda) maupun yang non-materi (seperti masalah, konsep, ide-ide). Sementara, obyek formal berarti dari sudut pandang mana suatu obyek itu diselidiki (Rusuli and M. Daud, 2015).

\section{SIMPULAN}

$\begin{array}{cccc}\text { Penggunaan kartu Learning } & \text { bergambar } \\ \text { bertujuan untuk mempermudah } & \text { mahasiswa }\end{array}$ memberikan asosiasi terhadap konsep dan materi sehingga gambar yang didapatkan mahasiswa dalam memunculkan ide-ide yang kreatif. Kartu tendang bergambar diharapkan mampu meningkatkan mahasiswa kemampuan spasial dan visual siswa. Masalah yang disampaikan oleh dosen pada saat pembelajaran berlangsung dapat dibantu pemecahannya melalui gambar tersebut.

Pada kartu Learning merupakan kartu yang berisikan kata kunci dalam pembelajaran yang digunakan mahasiswa dalam menyusun solusi, konsep dan pemecahan masalah baik secara runut dan sistematis. Penggunaan kata kunci ini tentu saja harus sangat berkaitan dengan konsep yang dilontarkan oleh Dosen. Pada kartu Learning berkata terjadi penyusun ide kedalam sebuah solusi yang mampu dilaksanakan.

\section{DAFTAR PUSTAKA}

Eliasa, E.I., 2014. Increasing Values of Teamwork and Responsibility of the Students through Games: Integrating Education Character in
Lectures. Procedia - Soc. Behav. Sci. 123, 196-203.

https://doi.org/10.1016/j.sbspro.2014.01.141 5

Holland, C., Ulrich, D., 2016. Critical thinking cards: An innovative teaching strategy to bridge classroom knowledge with clinical decision making. Teach. Learn. Nurs. 11, 108-112. https://doi.org/10.1016/j.teln.2016.01.005

Jäger, F., Riemer, M., Abendroth, M., Sehner, S., Harendza, S., 2014. Virtual patients: the influence of case design and teamwork on students' perception and knowledge - a pilot study. BMC Med. Educ. 14, 137. https://doi.org/10.1186/1472-6920-14-137

Jones, I., Alinier, G., 2015. Supporting Students' Learning Experiences through a Pocket Size Cue Card Designed around a Reflective Simulation Framework. Clin. Simul. Nurs. 11, 325-334.

https://doi.org/10.1016/j.ecns.2015.04.004

Kalisch, B.J., Aebersold, M., McLaughlin, M., Tschannen, D., Lane, S., 2015. An Intervention to Improve Nursing Teamwork Using Virtual Simulation. West. J. Nurs. Res. 37 , 164-179. https://doi.org/10.1177/0193945914531458

Nurdiansyah, Fariyatul Fahyuni, E., 2016. Inovasi Model Pembelajaran, Nizamial Learning Center.

Nurdyansyah, Fahyuni, E.F., 2016. Inovasi Model.

Nurhamsyah, D., Mendri, N.K., Wahyuningsih, M., 2015. PENGARUH EDUKASI TERHADAP PERUBAHAN PENGETAHUAN DAN SIKAP MAHASISWA TENTANG TRIAD KESEHATAN REPRODUKSI REMAJA (KRR) DI FAKULTAS ILMU SOSIAL DAN EKONOMI UNIVERSITAS RESPATI YOGYAKARTA 17.

Park, H.-R., Kim, C.-J., Park, J.-W., Park, E., 2015. Effects of team-based learning on perceived teamwork and academic performance in a health assessment subject. Collegian 22, 299-

http://jurnalilmiah.stikescitradelima.ac.id/index.php/JI Vol.4, No.2, Januari 2021 
305.

https://doi.org/10.1016/j.colegn.2014.05.001

Presti, C.R., 2016. The Flipped Learning Approach in Nursing Education: A Literature Review. J. Nurs. Educ. 55, 252-257. https://doi.org/10.3928/01484834-2016041403

Rodríguez-Carrio, J., Putrik, P., Sepriano, A., Moltó, A., Nikiphorou, E., Gossec, L., Kvien, T.K., Ramiro, S., 2018. Improving the peer review skills of young rheumatologists and researchers in rheumatology: the EMEUNET Peer Review Mentoring Program. RMD Open 4, e000619. https://doi.org/10.1136/rmdopen2017-000619

Rusuli, I., M. Daud, Z.F., 2015. ILMU PENGETAHUAN DARI JOHN LOCKE KE AL-ATTAS. Majelis Pendidik. Drh. Aceh 9, $12-22$.

Stigmar, M., 2016. Peer-to-peer Teaching in Higher Education: A Critical Literature Review. Mentor. Tutoring Partnersh. Learn. 24, 124136.

https://doi.org/10.1080/13611267.2016.1178 963

Tofil, N.M., Morris, J.L., Peterson, D.T., Watts, P., Epps, C., Harrington, K.F., Leon, K., Pierce, C., White, M.L., 2014. Interprofessional simulation training improves knowledge and teamwork in nursing and medical students during internal medicine clerkship: Interprofessional IM Simulation Course. J. Hosp. Med. 9, 189-192. https://doi.org/10.1002/jhm.2126

Vickrey, T., Rosploch, K., Rahmanian, R., Pilarz, M., Stains, M., 2015. Research-Based Implementation of Peer Instruction: A Literature Review. CBE-Life Sci. Educ. 14, es3. https://doi.org/10.1187/cbe.14-11-0198

Wahyudin D, S.R., 2011. Inovasi Pendidikan Dan Pembelajaran. Kurikulum Pembelajaran. 